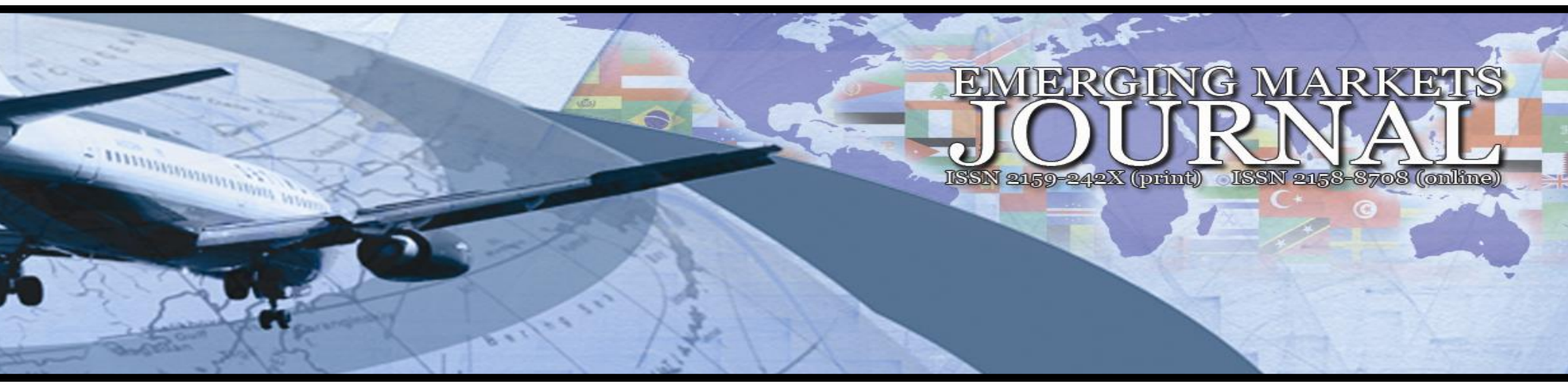

\title{
Joint-Stock Corporation under Turkish Commercial Law and the Doctrine of Increasing Shareholder Commitments
}

\section{Berna Tepe}

Doctor, Attorney at Law registered by the Istanbul Bar Association | e-mail: berntep@ymail.com

Volume 5 No 2 (2015) ｜ ISSN 2158-8708 (online) | DOI 10.5195/emaj.2015.85 | http://emaj.pitt.edu |

\section{Abstract}

The principle that the shareholder of a joint-stock company is under the single obligation of paying in his contribution to the equity-capital is in force within the framework of the 2011Turkish Commercial Code. It appears as if the reinforced principle of "single obligation "critically challenges the relevance of the formerly settled norm of subjecting increase in shareholders' commitments to unanimous consent of all shareholders. That being said, since the Turkish Commercial Code also contains deviations to the single obligation principle in addition to the fact that the notion of increase is shareholders' commitments was not made entirely obsolete from the Turkish Commercial Code, the doctrine for subjecting increases in shareholders' commitments to the general assembly's unanimous vote is to an extent still relevant within the context of the 2011 Turkish Commercial Code.

\section{$($ (c) $)$ EY}

New articles in this journal are licensed under a Creative Commons Attribution 3.0 United States License.

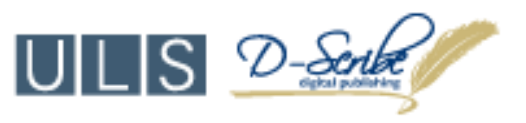

This journal is published by the University Library System of the University of Pittsburgh as part

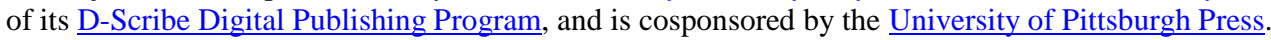


Joint-Stock

Corporation

under Turkish Commercial

Law and the Doctrine of

Increasing

Shareholder

Commitments

\section{Berna Tepe}

\section{Introduction $^{1}$}

Under Turkish law, commercial companies are comprised of a variety of commercially oriented entities: corporate partnerships, collective partnership and partnership in commendam, in addition to corporate capital companies, joint-stock corporation, limited liability corporation, partnership in commendam by shares in addition to the distinct cooperative partnership. The scope of the present article is related to joint-stock corporations for which the liability of each partner is, in principle, restricted with the amount of his concrete contribution for the constitution of capital and vis-à-vis the relevant company.

Each company regulated under the Commercial Code has legal capacity as an entity. For a corporation to enjoy its legal capacity distinct from the person(s) who provided for the constitution of the corporation, the corporate "will" needs to form ideally as a result of the deliberations within and by resolutions of the person(s) who have, as a rule, provided the equity-capital of the corporation, i.e., the general assembly of shareholders.

Corporate logic is based on investment for future gain and dependency among its various organs rather than immediate actualization of shareholders' own interests. For the actualization of company's economic objects such as to serve the interests of the shareholders in the long run, codependency exists between the company and the shareholder(s). Rule of majority reigns for the corporation to run rather than the independent will and intention of each shareholder which is relevant and "presumed" rather for creation of contracts. According to the Civil Code, Article 2, everyone should abide by norms of integrity when enjoying rights and discharging obligations while the legal order is not to protect abuse of a right. As such, a legal entity's enjoyment of its legal capacity by its machinations must end, the farthest, where another person starts. It is the shareholder who has expressed his will in order to establish a legal entity to perform commercial activity within the framework of an

1 All legislative clarifying statements referred to in the present article are accessible via www.basbakanlik.gov.tr. opted type of corporation. On the other hand, such will has been expressed for predictable if not specific terms of activity which must be maintained with a degree of legal security. Based on the foregoing, a condition which has prior importance is therefore whether the obligation favors the interests of the corporation for which the shareholder had legitimately expressed his will at the first place by participating to the corporation, as a reflection of the affectio societatis element of the memorandum of association.

Under Turkish law, three elements which distinguish the formation of a company from the formation of a regular contract, from an assembly of goods or an assembly of persons by law, constitute of (i) the contract, (ii) the persons, and (iii) the capital. Among them, "the contract's being a component of the company emphasizes that the company is a product of a consensual agreement" ${ }^{\prime 2}$. By rule, a type of consideration must be articulated for the formation of a contract, yet consideration is simply an object of exchange between the parties and therefore differs from the notion of capital. However, there is the characteristic of affectio societatis which further distinguishes a company from other contractual formations and also influences how the capital must be perceived: affectio societatis, "in its broader sense, expresses the intention of each shareholder to actively participate to the accomplishment of a company's purpose"3.

The corporation is not a representative of the shareholder who is a person separate from the corporation as well as from other shareholders. It is further noteworthy that, as an organ of a corporate company, the general assembly is composed of shareholders, each having a mindset on how the purpose and the objectives of the company within the framework of the company's purpose can be achieved while each considering also his own legitimate interests, accordingly asserting an individual will. Such distinction between the corporate interests and individual interests becomes very apparent, for instance, within the context of repurchase of own shares by a company; at a final analysis, "when a company repurchases its shares, it transfers company assets (the purchase price) to the members from whom the shares are purchased"4.

Therefore, is the shareholder really expected to act purely to the benefit of the shareholding separate from the shareholder's other legitimate interests? Taking the shareholder out of the equation for decisions which can however be imposed on any shareholder is neither fair nor realistic since such would keep the company too

\footnotetext{
2 Domaniç, Hayri “Anonim Şirketler Hukuku ve Uygulaması", Temel Yayınları, 1988, p.19.

${ }^{3}$ Domaniç, ibid., p. 27.

${ }^{4}$ Cahn, A. and Donald, D. "Comparative Company Law", Cambridge University Press, 2010, p. 241.
} 
independent from the shareholder's will and circle of interests.

Obligations which are sufficiently specific to which the shareholder has individually committed do not cause a concern since they are in conformity with the contractual logic. If "the shareholder is constrained to transfer a value above the amount he has committed to pay, or perform an act which has not been expected at the outset", if "a decision of the company obliges the shareholder to make an expense or discharge an obligation which was not present in the original agreements" ${ }^{\prime \prime}$, then there is a clear case of increase in shareholder obligations. Such occurrences generally arise due to reasons favoring the corporation or third parties. Although constraining the shareholder to obligations in an unagreed manner, not all cases may be that clear as explained. Some vices thrive in the absence of any detection. Therefore, framing certain obligations as shareholder commitments initially serves concerns of legal security. Secondly, the shareholder's will should be in line with the obligations which such shareholding is conducive to, that is in a predictable and measurable manner to the extent any contractual obligation must be while the principle of equality among shareholders under the same circumstances must also be satisfied.

In some countries, the doctrine of increasing shareholder commitments by unanimous vote, i.e. the requirement to seek unanimous vote of the general assembly, thereby consent of each shareholder whose commitments increase by various transactions of the company. In this article, it is analyzed to which extent this doctrine is relevant to joint-stock corporations under 2011 Turkish Commercial Code.

\section{Commitments of shareholders}

The classification adopted by the 2011 Turkish Commercial Code for personal commitments prioritize commitments of financial nature.

\section{Primary commitments}

A primary commitment of the shareholder consists of obligations and commitments which are to enable the formation of a company's capital: It is asserted in a provision common to all types of corporate companies of the 2011 Turkish Commercial Code that "each shareholder is liable vis-à-vis the company for the

5 Houpin and Bosvieux, "Traité général théorique et pratique des sociétés civiles et commerciales" vol. II, n 1262 , cited in Rizzo, Fabrice "Le principe d'intangibilité des engagements des associés" Revue trimestrielle de Droit commercial, 2000, p. $27 \mathrm{ff}$.

6 Hamel, Lagarde and Jauffret "Traité de droit commercial" vol. I, 1980, n 697, cited in Rizzo, Fabrice "Le principe d'intangibilité des engagements des associés" RevueTrimestrielle de Droit commercial, 2000, p. $27 \mathrm{ff}$. amount of capital it has undertaken in the memorandum of association duly draft and signed"7 .

The commitments that a shareholder can make in the form of obligations to the company for constitution of capital depend on the type of company. Registration of a commercial corporation by the commercial registry as well as acquiring title over its shares require the deposit of liquid or non-liquid assets. According to the 2011 Turkish Commercial Code, Article 581 and Article 342, liquidity and transferability determine the types of assets which can be deposited as capital: Commercial prestige, labor or other types of services cannot be deposited as capital to a limited liability corporation or a corporate capital company in a consecutive manner; such do not even qualify as an asset for the formation of capital.

As far as corporate capital companies are concerned, for both the limited liability corporation and the jointstock corporation, the major commitment of a shareholder vis-à-vis the company is the obligation to extend capital.

\section{Auxiliary commitments}

Generally speaking, there are commitments other than the obligation for the constitution of capital of a corporation. Especially when managing the capital of the company, the "will" of a corporation that is formed in an organizational manner is also inclined to ask for commitment, impose conditions or simply become part of situations which favorably or adversely acts upon shareholders' interests.

Financial commitments other than paying in capital can however be considered as commitments independent from the constitution of the capital. On the other hand, legal security requires that if a financial commitment is primarily of a contractual nature, it should abide by norms concerning contracts. ${ }^{8}$ para. 1

2011 Turkish Commercial Code, Article 128

${ }^{8}$ Legislative Clarifying Statement of the 2011 Turkish Commercial Code, Article 480, alinea (1), available at www.basbakanlik.gov.tr reads as: Madde 480 - Birinci fikra: 6762 sayll Kanunun m. 405 (1)'in bazl değișikliklerle - yerini alan ve tek borç ilkesine açıkça yer veren bu hüküm, anonim şirketlerde, Tasarı ile ona dayalı esas sözleşme düzenini egemen kılmayı, borçlar hukuku sözleş meleriyle oluşturulabilecek yan düzenin esas sözleşme düzenini ortadan kaldırmasına sinırsız bir sckilde izin vermemeyi amaçlamaktadır. "Paysahipleri sözleşmesi" veya "ortaklar sözleşmesi" diye Türkçeye çevrilen, ancak dünyada "shareholders agreement" terimi ile adlandırılan, bazen de "joint-venture sözleșmesi" bașlığını taşıyan, son yılların dünya çapında en "populer" atipik sözlesmesi olan bu sözleșme, yabancı öğretide kullanılan terim ile esas sözleşme düzeni yanında, çoğu kez ona ve kanuna hükmeden veya ikisini de birden bertaraf eden bir "yan düzen" yaratmiştır.

Ulusal hukukun uygun görmediği ve bu sebeple emredici hükümlerle koruma altına aldığ hemen hemen her menfaat veva hak (çoğu kez) yan düzenle ya zedelenmekte ya da sinırlandirlmaktadır. Bu yan düzen güçlüye, hukukunu getirmek, hakimiyet kurmak, istediği an istediği fiyatla karşı 
A difference between the limited liability corporation and the joint-stock corporation in terms of the explicit wording is that supplementary financial commitments are enabled by the 2011 Turkish Commercial Code, Article 573, para.2 relevant to the limited liability corporation. ${ }^{9}$ The component of person is much less prevalent as far as a joint-stock corporation is concerned such that a commitment is attached to the shareholding rather than to a certain person even when he has a single unit of shareholding at the company. Therefore, the principle of single obligation of the shareholder was introduced by the 2011 Turkish Commercial Code. The said principle is explicitly articulated in its Article 480, para.1 such that each shareholder is under the single commitment to contribute by capital for his shareholding. By barring the imposition of any obligation on him other than for his shareholding and, if applicable, any premium above the nominal value of the relevant shares, does the legislature mean to set the financial boundary of the shareholder of the typical jointstock company? The provision where the single obligation principle is asserted explicitly concerns the memorandum of association. That being said, according to the legislative clarifying statement of the specific provision, the underlying primary aim is upholding the memorandum of association as the constitution of the joint-stock corporation. The legislature sounds anxious not to legally acknowledge agreements in the 2011 Turkish Commercial Code since such agreements frequently thrive along the memorandums of association. On the other hand, even such aim as stated in the legislative clarifying statement is explicitly limited to not permit that contractual obligations and rights by means of agreements of which the formation is subject to the Code of Obligations override the clauses of the memorandum of association regulated by law.

It is noteworthy that the 2011 Turkish Commercial Code introduced a restrictive norm which is significant

tarafin payların almak veya paylarin satmak hakkin sağlamaktadır. Veto hakları da bu düzenin önemli silahıdır. Kara Avrupası hukukları olabildiği o--randa bu yan düzeni sinırlamaya çaba harcamaktadır.

Tek borç ilkesi, hükümde "esas sözleşmeyle pay sahibine, pay bedelini veya payın itibarî değerini aşan primi ifa dışında borç yükletilemez" şeklinde ifade olunmuştur. Bu hüküm, yan düzenin esas sözleşmeyle düzenlenmesine engel olduğu kadar emredici niteliği sebebiyle yan düzenin bazı hükümlerini sorgulanabilir konuma getirmektedir. Hüküm başka kanunlara engel olucu bir aracı içermemekte, bu görevi sintrlı bir şekilde 340 incı maddenin son cümlesi üstlenmis bulunmaktadır.

İlke yönünden 6762 sayll Kanunun 405 inci maddesinin birinci fikrasının ifadesinde değișiklik yapılmıștır. Mevcut metin "fazla bir şey ödemeye esas mukavele ile dahi mecbur tutulamaz" diy erek ödeme sözcügünü vurgulamıştı. Bu da, Türk ögretisinde, hükmün sermaye ve prim borcu dişındaki diğer para borçlarını kapsamadığı görüşünün ileri sürülmesine sebep olmuștu. Onun için 480 inci maddede "borç yükletilemez" ifadesi bilinerek kullanılmıştır. Hükümdeki borç sözcügü geniş anlam taşımaktadır.

${ }^{9}$ Cf. Can, M. E. "Limited Şirket Ortağının Borçları ve Yükümlülükleri”, Gazi University, Gazi Üniversitesi Hukuk Fakültesi Dergisi, 2011/4, p. 3. and relevant, also to the single obligation principle: According to its Article 340, the memorandum of association of a joint-stock cannot deviate from the provisions specified in relation to this type of company unless such a deviation is explicitly permitted by the Commercial Code. Moreover, provisions of another (statutory) act permissive of complementary clauses within a memorandum of association would be applicable within the framework of and limited to such an act. The rule of the 2011 Turkish Commercial Code sets forth a rule of interpretation and is meant to debar loopholes in the statutory regulation of joint-stock corporations ${ }^{10}$ and control the previously assumed liberty to get commitments from shareholders by various means, e.g. a shareholders' agreement parallel to a memorandum of association. Moreover, the legislator asserts in the legislative clarifying statement that the notion of "obligation" of the single obligation principle is to be conceived in its broad sense ${ }^{11}$.

Given the restrictive norm of interpretation, the provisions of the Code related to the joint-stock corporations are to be shed a brighter light on in order to detect any explicit wording which enables deviation from the single obligation principle. Indeed, within the context of conditions of amending the memorandum of association, the 2011 Turkish Commercial Code, Article 421, para.2, alinea (a) provides that a decision which imposes a liability to balance a negative account [or auxiliary liabilities/ (commitments)] requires unanimous vote of all shareholders at the general assembly. According to the scholarly opinion, the provision enables deviation from the single obligation principle only for the stated aim of balancing a negative account ${ }^{12}$. Nevertheless if that deviation calls for a change, it is possible by amending the memorandum of association by unanimous consent of all shareholders. Further, underlying the 2011 Turkish Commercial Code, it is stated in various provisions' legislative clarifying statements, viz. those of Article 391, Article 421, para.2, Article 476, para. 2, that balancing a joint-stock corporation's negative account constitutes an exception as a supplemental financial liability to be assumed by the shareholders while requiring unanimous consent of the shareholders.

To an extent, 2011 Turkish Commercial Code has dispensed with the notion of increase of shareholder commitments by adopting the principle of single

${ }^{10}$ Cf. R. Karasu, "6102 sayıl Türk Ticaret Kanunu'na geçen Anonim Şirketlerde Emredici Hükümler İlkesi”, 6102 sayll Yeni Türk Ticaret Kanunu'nu Beklerken" University of Marmara, Faculty of Law, Hukuk Araştırmaları Dergisi, 2012, Special Issue of the proceedings held between 10-12 May 2012, vol. 18, no.2, p. $311 \mathrm{ff}$

${ }^{1}$ Legislative Clarifying Statement of the 2011 Turkish Commercial Code, Article 480, alinea (1)

${ }^{12}$ Poroy, R, Tekinalp, T, and Çamoğlu, E. "Ortaklıklar ve Kooperatif Hukuku”, Vedat Kitapçılık, 2014, p. 607. 
obligation for the shareholder as far as joint-stock corporations are concerned. If attention is be paid to Swiss law, a clause providing an auxiliary commitment need to be individually analyzed to see whether the clause imposes an obvious financial burden to the shareholder. ${ }^{13}$

However, not all clauses are explicit as concerns the possible financial burden for a shareholder. The criteria of "obvious financial burden" has been used however in order to not permit occurrences where the financial loss for a shareholder was highly obvious and measurable rather than cases where the financial loss is not predictably measurable at the first place. For instance, getting a commitment from the shareholder as to subject his transfer of shares to a much lesser value than the market value is in fact a disguised restriction or even a prohibition on transferring shares.

\section{I.B. Other commitments of non-monetary type}

As a very general norm, commitments focused on performance can be made as to constitute capital of a company, as such enabling a shareholder to discharge its obligation to acquire shares by way of performing some acts. Indeed, performance commitments can be of commercial value for those who benefit even if they do not constitute assets as such. As a matter of fact, such is enabled by 2011 Turkish Commercial Code, Article 127 which states to be a provision applicable to all types of corporations unless provided otherwise by law ${ }^{14}$. Therefore, as a general rule, commitments for personal performance can be exchanged for title to corporate partnership. The related obligation is the performance of some act by the shareholder. Such acts are generally active labor or active management which are supposed to benefit the corporation. As a matter of fact, it has been an item of which the evaluation has been generally difficult or impossible to be represented and entered into corporate accounts in monetary terms. Nevertheless, the Turkish Court of Cassation pronounced in 1968 that a corporation is entitled to claim from the shareholder to perform his obligation. ${ }^{15}$ Unless the act cannot be performed due to reasons where the shareholder cannot be held liable for nonperformance ${ }^{16}$, then at worst, damages can be claimed from the shareholder. Therefore, even if the performance of such act has not been represented in monetary terms in the company accounts, the performance of an act still has a value as participation to the capital. If a personal performance commitment has been made by a shareholder, his shareholding is the

${ }^{13}$ Tekinalp et alias, ibid, p. 607

${ }^{14}$ For exceptions, see the subtitle below in the text of the present article.

${ }^{15}$ Decision of the Court of Cassation (Commercial) dated 26 November 1968, numbered 1968/6301.

${ }_{16}$ See, Nomer, Haluk "Borçlar Hukuku - Genel Hükümler”, Beta Basım A.S.., 2013, pp. 265 - 270. direct product of his commitment to perform unless there is a substantial reason not to reframe a commitment of personal performance as participation to the capital.

However, not all corporation types enable a shareholder to participate to the capital with personal performance. Indeed, 2011 Turkish Commercial Code, Article 581, Article 342 and Article 307 consecutively excludes acts of service and personal labor from the capital of a limited liability corporation, the capital of a joint-stock corporation and the capital extended by a partner whose liability is limited in a corporate partnership in commendam.

A further difference is introduced between the limited liability corporation and the joint-stock corporation: According to its explicit wording, auxiliary commitments are enabled by the 2011 Turkish Commercial Code, Article 573, para. 2 for the limited liability corporation while the joint-stock corporation is to be run primarily in accordance with the "principle" of single obligation assumed by the shareholder.

When the provision is construed as a principle, it calls for interpretation whether the principle is relevant only to financial commitments vis-à-vis the joint-stock corporation, or the "single obligation" principle is also meant to debar any other commitments especially if they are not monetary: The legislator asserts that "the notion of obligation of the single obligation principle is to be conceived in its broad sense" ${ }^{, 17}$.

Shareholder commitments are framed by the 2011 Code of Commerce as commitments for capital requirement, primary commitments and secondary commitments. The (i) commitment for capital requirement is well structured because the single obligation principle is primarily applicable to the constitution of capital; (ii) other primary commitments can arise only to balance a negative company account, therefore for the maintenance of capital; (iii) secondary commitments are not explicitly enumerated by law.

The 2011 Turkish Commercial Code, Article 421, para.2, alinea (a) is relevant in the present context since it enables imposition of an auxiliary liability to balance a negative account of the joint-stock corporation, that is by the unanimous vote of all shareholders at the general assembly. Since in various provisions' legislative clarifying statements, viz. those of Article 391, Article 421, para.2, Article 476, para. 2, it is clarified that balancing a joint-stock corporation's negative account and other commitments related to non-monetary performance constitutes an exceptional financial liability to be assumed by the shareholders.

${ }^{17}$ Legislative Clarifying Statement of the 2011 Turkish Commercial Code, Article 480, alinea (1). 
If the courts are to construe clauses as to whether they survive the single obligation principle, due regard is be paid to the implied financial burden on the shareholder if the clause is complied with. "Options" are put under focus from this regard: an option is a unilateral declaration of intention which gives the right to make an agreement or entitles the holder of the option to prolong an agreement ${ }^{18}$. Call and put options create legally qualified new occurrences initiated by unilateral declarations of intention extended by the holders of such options. The contract will be formed not before a declaration stemming from a call or put option, but once it has been received by the other party. Making an agreement by unilateral declaration of intention means that it does not matter whether other party accepts this declaration or not. The contract is formed upon the receipt of due notification.

Gained more weight upon the introduction of the 2011 Turkish Commercial Code, the scholarly opinion to the effect that while a call option is not viable due to the weakness of any related negotiations, the right of first offer survives the single obligation principle. ${ }^{19}$ The same scholarly works suggest that under Swiss Law, such clauses are tested by the implied financial burden if the commitment was abided by. ${ }^{20}$ From this perspective, there is no reason why should not be compatible with the single obligation principle, innocent options like the tagalong right of a minority shareholder who is vested with the right to join the deal and sell their stake at the same terms availed by the majority shareholder who is the initial seller.

We believe it is an artificial attempt to reframe obligations arising out of options as shareholder commitments. Since the legislature justifies introduction of certain provisions in the 2011 Turkish Commercial Code by the existence of critical risks which arise out of contractual agreements among the shareholders or between the shareholder(s) and the corporation, then such suggests the requirement to acknowledge that the legislature has taken on a regulatory attitude even for joint-stock corporations which are not publicly listed. The courts' judgment cannot be independent from such an attitude. It is pertinent to simply emphasize that law cannot protect abuse of any right. The shareholder's will should be in line with the implications of commitments for the shareholder and it should be taken into account in

${ }^{18}$ Buz, Vedat "Medeni Hukukta Yenilik Doğuran Haklar", Yetkin Yayınları, 2005, p. $160 \mathrm{ff}$.

${ }^{19}$ Poroy, R, Tekinalp, T, and Çamoğlu, E. "Ortaklıklar ve Kooperatif Hukuku”, Vedat Kitapçılık, 2014, p. 607. Cf. Bahtiyar, Mehmet "Anonim Ortaklıkta Payların Üçüncü Kişilere Satılması Durumunda Diğer Ortaklara Önalım Hakkı Tanıyan Anasözleşme Hükümleri ve Etkileri”, Banka ve Ticaret Hukuku Araştırma Enstitüsü, BATIDDER, vol. XXI, no. 2, 2001, pp. 94 95.

${ }^{20}$ Poroy, R, Tekinalp, T, and Çamoğlu, E. “Ortaklıklar ve Kooperatif Hukuku”, Vedat Kitapçılık, 2014, p. 607. the case of a contract, the law of parties meant to be formed is based on the shareholding. Such contractual obligations which aim to construct the law of the parties although they directly relate to a regulated area of law like the transferability of shares can only form and be maintained in a healthy manner if the liabilities can be assessed in a predictably measurable manner. Further, it should be possible to assert that there the contractual obligation is based on free will which have formed in a sufficiently concrete manner at the first place.

Moreover, it is stated in the 2011 Turkish Commercial Code, Article 480, para. (4) that in case transfer of shares is subjected to the approval of the joint-stock corporation, then in addition to the obligation to extend capital, commitments can be obtained from shareholders which require them to perform various acts in a periodical (/repetitive) manner provided that the subjectmatter is not monetary.

As concerns the subject-matter of such a commitment, the subject-matter being non-monetary calls for interpretation. Under both legal terminology as well as financial terminology, when the subject-matter is "nonmonetary", such excludes cash and not other rights, values or assets. Secondly, it is noteworthy that under Turkish law, (contractual) obligations are being classified in the doctrine also from the perspective of the frequency of performance involved in order to discharge an obligation: Obligations of instant performance, periodical performance and continuous performance constitute the types of obligations from this aspect ${ }^{21}$. Other than those specified in the 2011 Turkish Commercial Code, by enabling certain obligations of periodical performance in its Article 480, para. (4), the stated provision excludes other obligations of instant performance or continuous performance even if their subject-matters are nonmonetary.

Obligations based on continuous performance are based on various degrees of trust between its parties. Therefore in principle, the legislature maintains the previous understanding that a joint-stock corporation is not based on or meant to be conducive to an understanding where trust characterizes the relationship among the shareholders, or that between the corporation and the shareholder(s). ${ }^{22}$

The nature and scope of such commitments of periodical performance which are enabled by Article 480, para. (4) can be written on the back of the share certificates or receipts as applicable.

${ }^{21}$ See, Eren, Firket "Borçlar Hukuku - Genel Hükümler", Beta A.Ş., 2008, pp. 99 - 100 .

${ }_{22}$ See, Hamamcioğlu, Esra "Anonim Şirketlerde Anasözleşme Değiş̧ikliği”, $\mathrm{PhD}$ thesis in private law defended at the Marmara University, 2011, p. 28, accessible via www.yok.gov.tr. 
Finally, such legislative stance does not rule out regulation of critical risk by law or contract when it is the minority shareholder's legitimate interest which is at stake. Indeed, the 2011 Turkish Commercial Code enables by its Article 531 the minority shareholder(s) to request termination of the company due to rightful/legitimate reasons which can be conducive to such termination, transfer of shares or other suitable and acceptable solution by the decision of the court. Although of ex post effect, such statutory regulation of minority shareholder's risk is especially meaningful at situations where transfer of shares is subjected to the approval of the corporation.

Proscribing the shareholders from competing with the company is a shareholder commitment which can be analyzed in this vein. Rules as concerns noncompetition of shareholders with the company are contained in the 2011 Turkish Commercial Code, but vary depending on the type of company. Prohibition to compete may (further) be regulated within the memorandum of association of the relevant company. If no norm is specified in relation to a type of company, and if compatible, the 2011 Code of Obligations, Article 626 applies such that the shareholders cannot perform acts favorable to others while impeding the company's achievement of its objective or otherwise to the detriment of the company. It cannot be said that competitive activities or exercise of separate activities in the same sector as the company at which one is a shareholder are necessarily to the company's detriment. It calls for clarification albeit basic that the specified prohibition to compete is an extension of the duty of loyalty or is simply out of integrity. According to a legislative clarifying statement in relation to the 2011 Turkish Commercial Code which is noteworthy also in the present context, although the notion of shareholder loyalty neighbors the prohibition to compete, it is distinct from it. ${ }^{23}$

From the perspective of a corporation's interests, organizational sophistication of the company as a distinct entity, the shareholder's access to information, increased involvement in the company's business and right of vote are considered to justify a prohibition to compete. That being said, when it is a joint-stock corporation which is concerned, the general principle of "single obligation" of shareholders is deemed relevant also in terms of nonfinancial commitments; authors who conceive the term "obligation" in its broad sense and not just financial such as to validate the principle's restrictive effect on all types of commitments, emphasize that nonfinancial commitments could rather be sustained, if applicable, as

${ }^{23}$ Legislative Clarifying Statement for the 2011 Turkish Commercial Code, Article 613 re duty of loyalty (and proscription to compete) of shareholders of limited liability corporations. contractual obligations ${ }^{24}$. If it can be deduced from the "single obligation" principle that a shareholder of a jointstock corporation cannot be prohibited from competing with the company, than we assume that the prohibition to compete is a type of shareholder commitment which cannot be sustained even if contractually. Indeed, such commitments are among those occurrences which have provoked the regulatory attitude of the legislature and need to be weighed by courts also against principles and other rights which such commitments conflict with, in addition to taking into account the resulting financial burden for the shareholder. However such commitments cannot find a favorable justification at the 2011 Turkish Commercial Code as far as joint-stock corporations are concerned.

At situations where an obligation which consists of a periodical performance is enabled, obtaining a new performance commitment is conducive to following the procedure for amending the memorandum of association.

\section{Commitments for execution of preexisting commitments}

Given the single obligation principle as well as Article 421, para.2, alinea (a) and Article 480, para. 4 of the 2011 Turkish Commercial Code about other commitments, specifying each commitment is an ideal for the soundness of not only the original general commitment, but also that of an act in order to implement a clause or decision binding on the shareholder. The doctrine subjecting increase in shareholders' commitments to unanimous vote also emphasizes seeking shareholder consent for such acts of implementation would hamper the efficient functioning of a company. ${ }^{25}$ Such concern challenges any view that the obligations to which the shareholder has committed must been predictably measurable.

\section{Amending the Memorandum of Association}

Within the context of conditions of amending the memorandum of association, the 2011 Turkish Commercial Code, Article 421, para.2, alinea (a) provides that a decision which imposes a liability or auxiliary liabilities/commitments to balance a negative account requires unanimous vote of all shareholders at

\footnotetext{
${ }^{24}$ Poroy, R, Tekinalp, T, and Çamoğlu, E. "Ortaklıklar ve Kooperatif Hukuku”, Vedat Kitapçlık, 2014, p.529.

${ }^{25}$ Monsèrié-Bon, Marie-Hélène, "Encore l'augmentation des engagements des associés", Revue Trimestrielle de Droit Commercial, Dalloz, 2004, p. 551.
} 
the general assembly. Given the single obligation principle, the provision requires that in order to impose a liability to a shareholder as to balance a negative company, such should be with the decision of the general assembly which could decide favorably only with unanimous vote. When the provision is interpreted in a teleological manner, the purpose is to subject such impositions of liability to the favorable vote of all shareholders during the general assembly of the jointstock corporation.

\section{Mergers: Issues of increase in shareholder commitments}

When a merger is considered to require amendment of the relevant corporations' memorandum of association, such would be subject to the statutory and regulatory provisions regulating amendment of a corporation's memorandum of association. However, the 2011 Turkish Commercial Code regulates merger operations in a separate manner and distinct from the provisions related to amending memorandum of association.

\section{VI.A. Compatibility Between Types of Corporations}

The legislative clarifying statement of the 2011 Turkish Commercial Code, Article 137 is expressive rather about the limitation on liabilities vis-à-vis the creditors as an underlying reason behind the compatibility required between various types of companies that is by especially taking into account the form of the acquiring or the final emerging company.

A merger can realize by way of acquisition or by way of establishing a new incorporation. The 2011 Turkish Commercial Code, Article 137 ff specifies compatible types of companies which can merge.

The table below shows the companies compatible for merger, which can be analyzed in three main categories such as corporate capital companies, corporate partnerships and cooperative partnership. This classification is significant and an accepted one in the literature.
Table 1: Companies Compatible for Merger

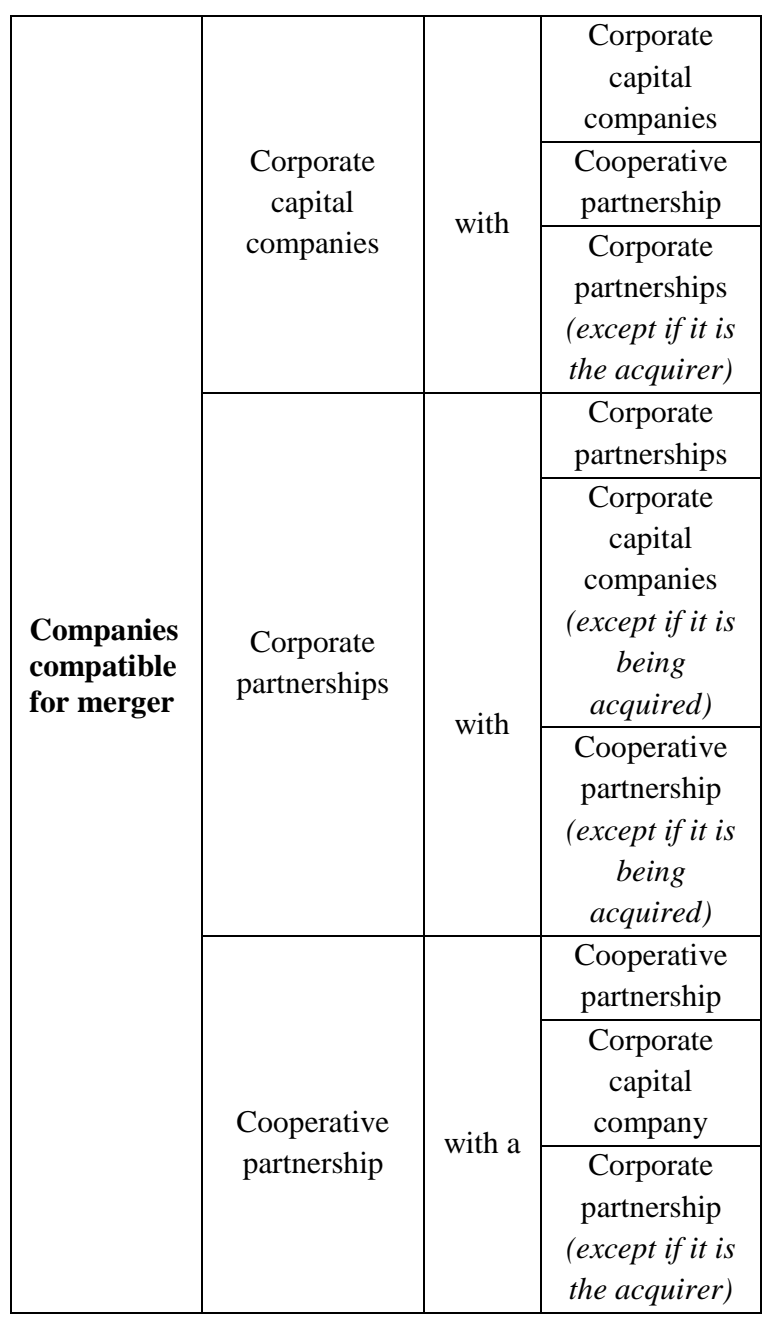

In essence, while introducing a distinction between corporate capital companies and corporate partnerships in its Article 124, para. 2, the 2011 Turkish Commercial Code does not allow for corporate partnerships to be the acquiring party when merging with a type of corporation other than that of such intended acquirer. That being said, the classification serves to determine whether the element of "persons" or rather the element of "capital" characterizes the delimitation of the shareholders' obligations and rights related to the corporation. ${ }^{26}$ At corporate partnerships, there is always a partner liable vis-à-vis the creditors of the company in an unlimited manner while shareholders of a corporate capital company do not accommodate such. ${ }^{27}$ The 2011 Turkish

${ }^{26}$ See Köse, ibid, p. 882

27 For collective corporations, see 2011 Turkish Commercial Code, Article 211 according to which partners are liable vis-à-vis the creditors of the corporation in an unlimited manner. For corporate partnerships in commendam, the 2011 Turkish Commercial Code, Article 304 and Article 319 are relevant in this context; individuals may become partners to the latter with unlimited liability vis-à-vis the creditors of the corporation in addition to any other person whose corporate partnership should be conducive to liability vis-à-vis the 
Commercial Code permits rather the corporate capital company to be the acquirer if a merger also involves a corporate partnership. Such principle is introduced thanks to another principle in its Article 158, the Code prevents release of those shareholders from liability from an obligation of the acquired partnership vis-à-vis the partnership's creditor for a period of three years starting from the date by which the decision for merger was publicly announced.

In essence, the point of focus for compatibility in mergers is the shareholder rather than the creditor. It can be deduced that the limitation on shareholder commitments from the perspective of the shareholder has been influential on the legislature's perspective for enabled mergers.

\section{B. Rule of Majority for Mergers}

The 2011 Turkish Commercial Code permits for a merger operation to be conducive to supplementary financial obligations, other personal performance commitments, personal duties or other obligations for the shareholders by the will of the merging corporations or due to the variation in the type of company merged into; according to the Commercial Code, Article 147, alinea $1(\mathrm{~g})$ and $(\mathrm{h})$, such duties should be made explicit in the merger report the draft of which is requisite. Even such merger report can be dispensed with under certain conditions sought by law.

The merger needs to be approved by the general assembly of the merging corporations unless the acquirer already holds a qualified majority of the other corporation's shares. For approval of the merger, the general assembly quora sought for equity-capital companies vary. For a limited liability corporation, the quorum sought is three-fourths of the shareholders which should be representative of three-fourths of the equitycapital. Apart from the limited liability corporation, as concerns the other two types of corporate capital company, viz. the joint-stock corporation or corporate partnership in commendam by shares, a quorum of threefourths is sought for the general assembly to approve the merger which should be representative of the majority of the actual or issued equity-capital as applicable.

The 2011 Turkish Commercial Code specifies that, the merger agreement "may" provide for a remunerated optout of the relevant company being subjected to merger. Moreover, it is explicitly permitted that the merger agreement provides only for remunerated opt-out ${ }^{28}$. That

creditors upto the amount he has participated to the equitycapital.

28 "Opt-out" is specified in 2011 Turkish Commercial Code, Article 141. being said, a provision for remunerated opt-out should be voted separately as to seek a quorum of ninety percent of the votes existing at a corporate capital company, or the unanimous vote of the shareholders vested with voting rights at a corporate partnership as applicable ${ }^{29}$.

\section{IV.C. Simplified procedure for mergers}

A point in legislation where the notion of increasing shareholder commitments has been held in consideration is when introducing a simplified procedure applicable to mergers. Only if recourse can be made to the simplified procedure for mergers, then it is not necessary to submit the merger agreement and other documentation to the general assembly. 2011 Turkish Commercial Code, Article 155, a merger can be effected by simplified procedure if the acquiring corporation owns all of the tobe-acquired company's shares vested with voting rights. Even if the acquirer owns not all, but at least ninety-five percent of the shares vested with voting rights, recourse to the simplified procedure is possible provided that the merger would not be conducive to any supplementary monetary liability, personal performance obligation or personal responsibility against the shareholder(s) holding the remainder. Therefore, the individual consent of such shareholders is sought to deviate from the full procedure for mergers according to which the merger agreement was to be vote by the general assembly.

IV.D. Requisite general assembly quorum for a decision on merger

As a rule, decisions of mergers need to be taken at the general assemblies of the involved companies after works involved in order to realize the merger. As concerns joint-stock companies whose shares are not listed on the stock-exchange markets, the decision quorum sought for the general assembly is three-fourths of those present at the assembly provided that such quorum represents the majority of the equity-capital or of the issued capital as applicable. Therefore, unless more than a quarter of those present at the general assembly opposes the merger, shareholder(s) representing the majority of the capital can issue a decision favorable to the merger.

The merger of a joint-stock corporation into a limited liability corporation is conducive to a regime which is not covered by the single obligation principle applicable to joint-stock corporations. Indeed, pursuant to the 2011 Turkish Commercial Code, Article 151, para.4., when a joint-stock corporation is to be acquired by a limited liability company and if the merger is conducive to or increases auxiliary commitments or personal performance commitments, then the merger should be

${ }^{29} 2011$ Turkish Commercial Code, Article 151, para.5, 
approved by unanimous vote of the relevant general assembly. Such requirement is parallel to the doctrine of increase of shareholders commitments.

\section{V. $\quad$ Recourse to the judiciary for violation}

A general assembly decision can contravene the principles or other norms concerning shareholder commitments by failing to satisfy procedural requirements, the quorum sought or due to its content.

\section{V.A. Challenging a general assembly decision}

\section{A.1. Action to have a general assembly decision} rescinded

2011 Turkish Commercial Code provides that a general assembly decision in violation of statutory norms, or the memorandum of association, and especially a decision not observing norms of integrity can be rescinded by a request to the commercial court. 2011 Turkish Commercial Code, Article 446 is worded as to entitle shareholders, the board of directors and members of the board of directors in an individual manner.

(1) Such a shareholder who can ask for rescission should be in a position to either (i) prove that their interest in such a result as requested is not only legitimate, but also they have opposed to the decision in the general assembly, or (ii) justify that he's entitled to initiate an action by asserting that failures to comply with certain procedural rules are (at least) among those factors which enabled such a decision to be taken. The provision's wording reads such that a shareholder cannot avail of this course of action if he simply did not or could not oppose the decision except if a procedural failure was influential in enabling the decision to being taken;

(2) Also the board of of directors is entitled to initiate an action for rescission in its capacity as an organ of the corporation;

(3) Even a member of the board of directors can lodge for the rescission of such a general assembly decision if he would be vulnerable to a risk of being held liable for executing the relevant decision.

Different from requests for rendering a general assembly decision null and void, action for rescission should be initiated within a term of three months starting from the date by which the decision was issued.

\section{A.2. Action to render a general assembly decision} null and void

A novelty of the 2011 Turkish Commercial Code is the provision that a general assembly decision can be declared null and void, that is acknowledging the invalidity of a decision, in addition to situations where a general assembly is rescinded. Taking into account rather the "content" of the decision, a general assembly decision can be declared to be null and void according to Article 447 if the decision restricts a shareholder's right which stems from the law or contravenes the main structural features of joint-stock corporations.

V.B. Comparison of the two types of actions against a general assembly decision

Despite the substantive and procedural differences between rescission of a general assembly decision and declaring it null and void, the 2011 Turkish Commercial Code regulates common points of these actions. The 2011 Turkish Commercial Code specifically provides certain interim measures upon pleadings that is while hearing a case for rescission of a general assembly decision, or to declare it null and void:

(i) the board of directors is required to duly announce the pleadings and the date of hearing, as such especially have that information announced on the internet site of the relevant company;

(ii) after hearing the board of directors on the matter, the court may - in the interim rule for suspense of the relevant decision;

(iii) the court may order the plaintiff to deposit a caution for an eventual loss of the relevant company to arise due to the proceedings. If the court orders deposit of a caution upon the defendant's request, the court is to decide on the type and amount of the caution.

Different from grounds for rescission however, grounds for declaring a general assembly decision null and void stems from concerns of public order. Within the context of the present subject analyzed, it is noteworthy that according to the doctrine subjecting increase of shareholders commitments to unanimous vote, "in order to sue for having such a general assembly decision null and void, it is not necessary to have voted against it" ${ }^{\text {"30; }}$ such approach is valid if the single obligation principle is considered not to override, but to be taken in conjunction with the doctrine in a manner as to form a main structural feature of the joint-stock company constituting a norm of public order.

Finally, whether for rescission or declaring a general assembly decision null and void, a favorable court ruling would be effective with regard to all shareholders and not just those persons who have initiated the action.

${ }^{30}$ Saintourens, Bernard "L'annulation, à la demande d'un associé, d'une décision d'assemblée emportant augmentation des engagements des associés votée à l'unanimité", Revue des sociétés 2004 p. 97. 


\section{V.C. Challenging the validity of a resolution of the board of directors}

Another possibility is that a resolution of the board of directors contravenes the principles or other norms concerning shareholder commitments by failing to observe especially the separation of functions or due to the content of the resolution.

\section{C.1. Action for rescission of a resolution}

At a private joint-stock corporation, if the board of directors has been authorized to increase the equitycapital of the company up to the registered amount of equity-capital, the 2011 Turkish Commercial Code, Article 460, para.1 enables the board to decide for increasing the equity-capital in accordance with the Code and within the limits of its power set forth by the company's memorandum of association. As such, for the board of directors to issue shares for a value above the nominal value or restrict the existing shareholders' rights to acquire new shares, it is required that the board's authority is provided by the memorandum of association. In case of failure to observe the said rules, 2011 Turkish Commercial Code, Article 460, para. 5 permit recourse to the court aiming at rescission of such a board resolution. By explicit reference of the Code, its provisions from Article 448 to 451 relevant to the rescission of a general assembly decision applicable to joint-stock corporations are applicable also in respect of the rescission of such a resolution of the board of directors.

\section{C.2. Action to render a resolution null and void}

The 2011 Turkish Commercial Code, Article 391 enables the competent court to "declare" a resolution of the board of directors null and void "particularly" for lack of conformity with mandatory provisions and for lack of conformity with main principles in respect of the functioning of a joint-stock corporation. Such main principles include acting in accordance with the main structure of a joint-stock corporation as well as separation of functions among the company's bodies.

\section{CONCLUSION}

The relevance of the doctrine of increasing shareholder commitments by unanimous consent of shareholders was critically weakened in the 2011 Turkish Commercial Code owing to the reinforcement of the single obligation for the shareholder as a principle as far as joint-stock corporations are concerned. The legislature rather emphasizes other principles as genuineness of capital, principle of single shareholder obligation and maintenance of capital which moreover figure as structural features of the joint-stock corporation. Nevertheless, due to the deviations from the single obligation principle, the doctrine concerning increase in shareholder commitments is not entirely overridden. For instance, the notion of increase of shareholder commitments is preserved with respect to mergers absorbing a joint-stock corporation. Further, the distinction introduced by the referred doctrine in France as concerns the difference between reduction of rights and increase in shareholder commitments can be considered pertinent within the 2011 Turkish Commercial Code: if a shareholder right or interest is reduced or not sustained, per se, such does not translate to an obligation for the shareholder, therefore not by itself challenging the single obligation principle. We exposed certain normative as well as theoretical grounds for the referred doctrine to be upheld in conjunction with the principle of single obligation. Finally, such analysis is meant to support resolution of conflicts in a healthy manner rather than trying to construe the 2011 Turkish Commercial Code in a manner totally detached from the past case-law arising from the referred doctrine when relevant.

\section{REFERENCES}

Bahtiyar, Mehmet “Anonim Ortaklıkta

Payların Üçüncü Kişilere Satılması

Durumunda Diğer Ortaklara Önalım

Hakkı Tanıyan Anasözleşme

Hükümleri ve Etkileri”, Banka ve

Ticaret Hukuku Araştırma Enstitüsü,

BATIDER, vol. XXI, no. 2, 2001, pp.

83-127.

Cahn, A. and Donald, D. "Comparative Company Law", Cambridge University

Press, 2010.

Domaniç, Hayri “Anonim Şirketler Hukuku ve

Uygulaması”, Temel Yayınları, 1988.

Eren, Fikret "Borçlar Hukuku - Genel Hükümler”, Beta Basım A.Ş., 2008. 
European Parliament, "Rights and obligations of shareholders: National regimes and proposed instruments at EU level for improving legal efficiency” May 2012, accessible via http://www.europarl.europa.eu

Hamamcioğlu, Esra “Anonim Şirketlerde Anasözleşme Değişikliği”, $\mathrm{PhD}$ thesis defended at Marmara University, 2011, accessible via www.yok.gov.tr

Hamel, Lagarde and Jauffret, "Traité de droit commercial", Dalloz, 1980.

Karasu, Rauf “6102 say1lı Türk Ticaret Kanunu'na göre Anonim Şirketlerde Emredici Hükümler İlkesi”, 6102 sayılı Yeni Türk Ticaret Kanunu'nu Beklerken" University of Marmara, Faculty of Law, Hukuk Araştırmaları Dergisi, 2012, Special Issue of the proceedings held between 10-12 May 2012, vol. 18 , no.2, pp. $311-332$.

Köse, Levent “Türk Anonim Ortaklıklar Hukukunda Sözü Edilen Tek Borç İlkesi ile Doktrin ve Tasarının İlkeye Bakışı”, İstanbul Barosu Dergisi, 2010/2, pp. $882-885$.

Monsèrié-Bon, Marie-Hélène, "Encore l'augmentation des engagements des associés", Revue Trimestrielle de Droit Commercial, Dalloz, 2004 p. 551.
Nomer, Haluk "Borçlar Hukuku - Genel Hükümler”, Beta Basım A.Ş., 2013.

Petit and Reinhard "Augmentation des engagements des actionnaires", Revue Trimestrielle de Droit Commercial, 1996, p. 487.

Poroy, R, Tekinalp, T, and Çamoğlu, E. "Ortaklıklar ve Kooperatif Hukuku", Vedat Kitapçılık, 2014.

Rizzo, Fabrice "Le principe d'intangibilité des engagements des associés", Revue Trimestrielle de Droit Commercial, Dalloz, 2000, p. 27. 